\title{
An empirical study on measuring the impact of personality type on employee capabilities
}

\author{
N. Sha'bani ${ }^{a^{*}}$, S. Salajeqe ${ }^{b}$, M. Fallah ${ }^{c}$, S.E.Najafi ${ }^{d}$ and N. Shahsavari Pour ${ }^{\mathrm{e}}$ \\ ${ }^{a}$ Department of Management, rafsanjan Branch, Islamic Azad University, Kerman, Iran \\ ${ }^{b}$ Department of Management, Kerman Branch, Islamic Azad University, Kerman, Iran \\ ${ }^{c}$ Department of Industrial Engineering, South Tehran Branch, Islamic Azad University, Tehran, Iran \\ ${ }^{d}$ Department of Industrial Engineering, Science and Research Branch, Islamic Azad University, Tehran, Iran \\ ${ }^{e}$ Department of Industrial Engineering, Kerman Branch, Islamic Azad University, Kerman, Iran
}

\begin{tabular}{|c|c|}
\hline ARTICLE I NFO & A B S T R A T \\
\hline $\begin{array}{l}\text { Article history: } \\
\text { Received } 25 \text { August } 2010 \\
\text { Received in revised form } \\
7 \text { December } 2010 \\
\text { Accepted } 3 \text { December } 2010 \\
\text { Available online } \\
8 \text { December } 2010 \\
\text { Keywords: } \\
\text { Personality type }\end{array}$ & $\begin{array}{l}\text { Personality is a stable set of characteristics and tendencies, which specifies similarities, and } \\
\text { differences of people' psychological behavior. Personality is normally a permanent behavior } \\
\text { through time and may not be comprehended easily or recognized as immediate or direct } \\
\text { situations due to some environmental and social stresses. In this paper, we study the } \\
\text { relationship between employees' personality and ability types. The paper identifies that there } \\
\text { are some relationships between employees' personality type and their ability. There is also a } \\
\text { relationship between introvert, extrovert, sensitive, emotive, thoughtful, considerate and } \\
\text { judging personality type and employees' ability. }\end{array}$ \\
\hline
\end{tabular}

Employee ability

Empowerment

Big fives

\section{Introduction}

Personality is one of effective factors cause individual differences and abilities. Occupation is one of the basic activities of life and personality factor plays an important role in choosing an appropriate job. Therefore, it is essential to study on the relationship between personality theories and job selection. Empowerment presents potential capacities needed for utilizing human abilities which are not applied completely, and it must be monitored carefully (Hersey \& Blanchard, 1989, Stephen, 2007). It enables us to utilize wisdom, skill, experience and motive all personnel. There is also a set of stable and relatively fixed exclusive properties for every one called personality. Hsu and Chan (1994) investigated the relationship between the inspector's personal type and the quality of

* Corresponding author. Tel: +09138457343

E-mail addresses: nader111350@yahoo.com (N. Sha'bani), 
inspection. They performed a factor analysis and indicated that four personal factors of stability, enthusiasm, sensitivity, and suspicion could affect the quality of inspection. Bradley and Hebert (1997) studied the relationship between the personal type on team performance. They analyzed the attributes of two development teams based on age, intelligence, problem-solving ability, task responsibility, and personality-type composition. They reported that there were no significant differences in the two teams other than the changes in personality-type mixture. In other words, personality-type composition was recognized as the only factor to determine the differences in team performance.

Bozionelos (2004) investigated the relationship between the big five of personality and work involvement with a sample of white-collar workers, who were employed on a full-time basis in clerical, administrative and managerial positions. The study suggested the existence of relationship between the big five of personality and work involvement. Diamantopoulos et al. (2005) empirically investigated the effect of brand extensions on brand personality. Robie et al. (2005) studied whether the so-called big five personality factors operate similarly from a psychometric perspective across dissimilar cultures by performing the investigation on US and Japanese's working environments. They chose two samples from two countries and performed factor analysis. Based on their findings, they reported that big five personality dimension scores were substantially higher in the US sample compared to the Japanese sample. Aryanezhad et al. (2010) proposed a BSC-DEA method to measure the relative performance of banking industry. In their method, they indicated that learning process plays an important role on increasing the relative performance of an organization. Najafi et al. (2011) presented a cause and effect relationship between the processes and human factors to measure the relative efficiency of banking industry.

This paper is organized as follows. We first present the problem definition in section 2. Section 3 presents the implementation of the proposed method and discusses the findings. Finally, concluding remarks are given in the last section to summarize the contribution of the paper.

\section{Problem Statement}

Personality is an organized and unit set including relatively stable and permanent characteristics which differentiates a person from another one. It is also a set or combination of psychological properties for classifying people (Robbins, 2007). Empowerment is designing and preparing an organization in which personnel are prepared to accept more responsibilities in addition to controlling themselves. Empowerment means to encourage personnel to be more active in their position and to take the responsibility of their improvement. The following are some of the most effective factors of personnel's empowerment.

- Individual factors: education, job experience, gender, race, control point, self-esteem

- Group factors: group effectiveness, group importance, group internal assurance, group members' understanding about their effect on managers

- Organizational factors: position ambiguity, resource availability, control domain, information availability, social support

There are also some factors which are considered as serious obstacle for empowerment process. Some of the most important ones are formal and hierarchical structure, low reliance and trust, managers' inappropriate attitude toward employees, lack of necessary skills, personnel's personality differences and stresses in working environment.

The primary objective of this paper is to study the employees' personality types and their abilities in governmental organizations. It also studies the relationship between the personality type and abilities. We also study introvert, extrovert, talented, sensitive, emotive, thoughtful, considerate and judging personality type and analyze their relationships with employees' abilities. 


\subsection{Conceptual Model}

In order to study the impacts of different factors on personality type we have performed an empirical analysis for a university located in a city called Kerman which is a city in the center of Iran. The university has 1915 employee and the sample size is calculated as follows,

$$
N=Z_{\alpha / 2}^{2} \frac{p \times q}{e^{2}},
$$

where $N$ is the sample size, $p=1-q$ represents the probability, $z_{\alpha / 2}$ is CDF of normal distribution and finally $\varepsilon$ is the error term. For our study we assume $p=0.5, z_{\alpha / 2}=1.96$ and $e=0.99$, the number of sample size is calculated as $N=320$. Table 1 demonstrates the personal characteristics of the people who participated in our survey.

\section{Table 1}

Personal characteristics of the respondents

\begin{tabular}{lllllllllll}
\hline \multicolumn{1}{c}{ Sex } & \multicolumn{1}{l}{ Education Background(Years) } & Age & & & \\
\hline Man & Woman & $<12$ & 12 & 14 & 16 & $>18$ & $20-30$ & $31-40$ & $41-50$ & $>50$ \\
\hline 198 & 121 & 6 & 54 & 70 & 157 & 35 & 62 & 124 & 112 & 23 \\
\hline 62.1 & 37.9 & 1.9 & 16.8 & 21.7 & 48.8 & 10.8 & 19.3 & 38.6 & 34.9 & 7.2 \\
\hline
\end{tabular}

As we can observe from Table 1, our sample size incorporates more men than woman and most of the people who took part in our survey are highly educated. Table 2 also shows the work experience of the participants.

\section{Table 2}

Personal characteristics of the respondents

\begin{tabular}{lllll}
\hline Work Experience(Years) & & & \\
\hline$<5$ & $6-10$ & $11-15$ & $21-25$ & $26-30$ \\
\hline 46 & 45 & 51 & 74 & 53 \\
\hline $14.4 \%$ & $14.1 \%$ & $15.9 \%$ & $23.1 \%$ & $16.6 \%$ \\
\hline
\end{tabular}

According to Table 2, over 85 percent of the population of our sample size has at least five years of job experience. This would increase the chance of gathering precise data regarding our survey. Table 3 summarizes the null hypothesis used for our survey.

\section{Table 3}

The necessary hypotheses concerning the relationship between empowerment and other influencing factors

\begin{tabular}{ll}
\hline Item & Hypothesis \\
\hline H1-1 & $\begin{array}{l}\text { There is a direct and positive relationship between the empowerment and personality } \\
\text { type. } \\
\text { H1-2 }\end{array}$ \\
$\begin{array}{l}\text { There is a direct and positive relationship between the empowerment and personal } \\
\text { abilities. } \\
\text { H1-3 }\end{array}$ & There is positive correlation between the employees' personality type and ability.
\end{tabular}

In order to have a better insight about the details impacts of personality type and abilities we proposed a set of secondary questions given in Table 4. In order to examine the hypothesis given in Table 3 and Table 4, we assume personality type and employees' ability as predicting and criteria variants, respectively. Moreover, we consider age, experience, education and gender as middle variant. We use two questionnaires to evaluate personality types and employees' ability.

The responses are gathered based on Likert scale from one to five. In the preliminary stage, we asked five university professors to confirm the questionnaires by replying the questions and the results 
validated the personality types and the employees' ability with $90 \%$ and $91 \%$, respectively. We also evaluated the reliabilities of the questionnaires and they were confirmed by $80 \%$ and $83 \%$ for personality types and employees' ability, respectively.

\section{Table 4}

The necessary hypotheses concerning the relationship between the employees' ability and other influencing factors

\begin{tabular}{|c|c|}
\hline Item & Hypothesis \\
\hline H2-1 & $\begin{array}{l}\text { There is a direct and positive relationship between the introvert personality type and } \\
\text { employees' ability. }\end{array}$ \\
\hline $\mathrm{H} 2-2$ & $\begin{array}{l}\text { There is a direct and positive relationship between the extrovert personality type and } \\
\text { employees' ability. }\end{array}$ \\
\hline $\mathrm{H} 2-3$ & $\begin{array}{l}\text { There is a direct and positive relationship between the talented personality type and } \\
\text { employees' ability. }\end{array}$ \\
\hline $\mathrm{H} 2-4$ & $\begin{array}{l}\text { There is a direct and positive relationship between the sensitive personality type and } \\
\text { employees' ability. }\end{array}$ \\
\hline $\mathrm{H} 2-5$ & $\begin{array}{l}\text { There is a direct and positive relationship between the emotive personality type and } \\
\text { employees' ability. }\end{array}$ \\
\hline H2-6 & $\begin{array}{l}\text { There is a direct and positive relationship between the thoughtful personality type and } \\
\text { employees' ability. }\end{array}$ \\
\hline $\mathrm{H} 2-7$ & $\begin{array}{l}\text { There is a direct and positive relationship between the considerate personality type } \\
\text { and employees' ability. }\end{array}$ \\
\hline H2-8 & $\begin{array}{l}\text { There is a direct and positive relationship between the judging personality type and } \\
\text { employees' ability. }\end{array}$ \\
\hline
\end{tabular}

\section{The results}

In this section, we discuss the results of our study for the proposed model of the paper. Table 5 summarizes the details of our finding on the personality type variants. For each item, we report the average, median, mode, maximum, minimum and the number of questions with no response. According to Table 5, the personality type of an employee has a strong relationship with his/her introvert personality type while it has the minimum relationship with his/her judging personality type. The survey indicates that the personality type of an employee is mostly reflected into introvert and considerate personality types.

\section{Table 5}

Description of personality types variants

\begin{tabular}{llllllll}
\hline Item & Variant & Average & Median & Mode & Maximum & Minimum & Blank \\
\hline 1 & Personality types & 3.08 & 3 & 3 & 5 & 1 & 2 \\
2 & Introvert personality type & 3.64 & 4 & 4 & 5 & 1 & 2 \\
3 & Extrovert personality type & 2.74 & 3 & 4 & 5 & 1 & 2 \\
4 & Emotive personality type & 3.12 & 3 & 3 & 5 & 1 & 3 \\
5 & Talented personality type & 2.99 & 3 & 3 & 5 & 1 & 2 \\
6 & Sensitive personality type & 2.80 & 3 & 4 & 5 & 1 & 2 \\
7 & Thoughtful personality type & 2.99 & 3 & 4 & 5 & 1 & 2 \\
8 & Considerate personality type & 3.44 & 3.5 & 3 & 5 & 1 & 2 \\
9 & Judging personality type & 2.63 & 2 & 2 & 5 & 1 & - \\
\hline
\end{tabular}


Table 6 also summarizes the results of our survey on how an employee's feeling could affect his/her abilities.

\section{Table 6}

Description of employees' ability variant

\begin{tabular}{llllllll}
\hline Item & \multicolumn{1}{c}{ Variant } & Average & Median & Mode & Maximum & Minimum & Blank \\
\hline 1 & Employees' ability & 3.52 & 4 & 4 & 5 & 1 & - \\
2 & Feeling of deserving & 3.33 & 4 & 4 & 5 & 1 & 1 \\
3 & Feeling of self-authority & 3.46 & 4 & 4 & 5 & 1 & 3 \\
4 & Feeling of effectiveness & 3.57 & 4 & 4 & 5 & 1 & 4 \\
5 & Feeling of purposeful job & 3.94 & 4 & 4 & 5 & 3 & 2 \\
6 & Fleeing of trust & 4.47 & 5 & 5 & 5 & 3 & - \\
\hline
\end{tabular}

As we see from the results of Table 6, feeling of trust is believed to be the most important issue on increasing an employee's ability. Feeling of purposeful job is the second most important item on increasing an employee's ability and the other three feelings are also considered to be good motivation on increasing the employees' abilities.

We have performed a correlation test between an employee's personal type and his/her abilities using the proposed questionnaire. The statistical results of Espearman and Condal tests indicate that the correlation numbers are 0.49 and 0.42 , respectively. The results also indicate that null hypothesis of having no relationship between the personal type and his/her abilities is rejected with the $p$-value of 0.000 .

As we explained earlier in this section, there are some secondary hypothesizes in our study. One of them is associated with the relationship between two variants of introvert personality types and employees' ability. The null hypothesis is rejected with the confidence level of $95 \%$ and the Espearman and Condal tests are calculated as 0.44 and 0.52, respectively. In other word, there is a strong relationship between the employee's abilities and introvert personality type. The other hypothesis is associated with the relationship of extrovert personality type and employees' ability. The results of this study indicates that the Espearman and Codal tests are 0.28 and 0.35 , respectively and the null hypothesis is rejected since the p-value is calculated as 0.000 which is less than the significance level of $5 \%$. As we can observe, there is a relatively good relationship between the extrovert personality type and employees' abilities. Table 7 summarizes the results the details of all hypotheses.

Table 7

The relationship between employee's abilities and other factors (Significant level $=5 \%$ )

\begin{tabular}{|c|c|c|c|c|}
\hline Factor & Espearman & Condal & Significant level & Result \\
\hline Introvert personality types & 0.44 & 0.52 & 0.000 & Rejected \\
\hline Extrovert personality type & 0.28 & 0.35 & 0.000 & Rejected \\
\hline Talented personality type & 0.39 & 0.43 & 0.000 & Rejected \\
\hline Sensitive personality type & -0.30 & -0.36 & 0.000 & Rejected \\
\hline Emotive personality type & 0.30 & 0.36 & 0.000 & Rejected \\
\hline $\begin{array}{l}\text { Thoughtful } \\
\text { type }\end{array}$ & 0.58 & 0.49 & 0.000 & Rejected \\
\hline $\begin{array}{l}\text { Considerate personality } \\
\text { type }\end{array}$ & -0.40 & -0.48 & 0.000 & Rejected \\
\hline Judging personality type & 0.31 & 0.35 & 0.000 & Rejected \\
\hline
\end{tabular}


As we can observe from Table 7, all eight factors significantly influence the abilities of an employee either positively or negatively. According to the results, the employees who are more sensitive and conservative tend to have less ability to contribute to the firms they work for. On the hand, an employee who has a thoughtful personality type can strongly increase his/her ability to contribute. Based on the results of this survey we may assign different tasks to appropriate people. Obviously, there are positions, which require problem solver employees, and we may choose the employees based on their personal characteristics and background working knowledge and experience.

\section{Conclusion}

In this paper, we have studied the impact of different personality type characteristics on empowerment of the employees of an organization. The study was focused on an educational organization with about 2000 workers and we selected a sample size of 320 employee. The survey distributed some questionnaire with various questions regarding their personal characteristics such as age, work experience, etc. The survey also gathered their opinion on the impact of different factors on personality type. We statistically analyzed the results and found out that there are personal characteristic such as thoughtful personal type and introvert personality type that could significantly influence the employee's ability, positively. There are other types of personal characteristics with negative impact on employee's ability such as sensitive or considerate personality type.

\section{Acknowledgement}

The authors would like to thank the anonymous referees for their comments on earlier version of this paper.

\section{References}

Aryanezhad, M. B., Najafi, E., \& Bakhshi Farkoosh, S. (2010). A BSC-DEA approach to measure the relative efficiency of service industry: A case study of banking sector. International Journal of Industrial Engineering Computations, doi: 10.5267/j.ijiec.2010.03.004.

Bradley, J. H., \& Hebert, F. J. (1997). The effect of personality type on team performance. Journal of Management Development, 16(5), 337-353.

Bozionelos, N. (2004). The big five of personality and work involvement. Journal of Managerial Psychology, 19(1), 69-81.

Diamantopoulos, A., Smith, G., \& Grime, I. (2005). The impact of brand extensions on brand personality: experimental evidence. European Journal of Marketing, 39(1/2), 129-149.

Hsu, S. H., \& Chan, T. (1994). A study of inspection performance and the personality of quality inspectors. International Journal of Quality \& Reliability Management, 11(3), 55-65.

Hersey, P., \& Blanchard, K. H. (1989). Management of organizational behavior, utilizing Human Resources, $5^{\text {th }}$ ed, Englewood Cliffs, New Jersey: Prentice Hall, Inc.

Najafi, S. E., Ahmadi, S. A., Fallah, M., \& Shahsavaripour, M. (2011). A cause and effect two-stage BSC-DEA method for measuring the relative efficiency of organizations. Management Science Letters, 1(1), 41-48.

Robbins, S. P. (2007). Organizational Behavior, $13^{\text {th }}$ ed., Prarson/Prrnticr Hall.

Robie, C., Brown, D. J., Bly, \& P. R. (2005).The big five in the USA and Japan. Journal of Management Development, 24(8), 720-738. 